\title{
Microbial Resources, Fermentation and Reduction of Negative Externalities in Food Systems: Patterns toward Sustainability and Resilience
}

\author{
Vittorio Capozzi $^{1}$ (®), Mariagiovanna Fragasso ${ }^{2}$ and Francesco Bimbo $^{2, *}$ \\ 1 Institute of Sciences of Food Production, National Research Council (CNR), c/o CS-DAT, Via Michele Protano, \\ 71121 Foggia, Italy; vittorio.capozzi@ispa.cnr.it \\ 2 Department of Agriculture, Food, Natural Science, Engineering, University of Foggia, 71121 Foggia, Italy; \\ mariagiovanna.fragasso@gmail.com \\ * Correspondence: francesco.bimbo@unifg.it
}

Citation: Capozzi, V.; Fragasso, M.; Bimbo, F. Microbial Resources, Fermentation and Reduction of Negative Externalities in Food Systems: Patterns toward Sustainability and Resilience. Fermentation 2021, 7, 54. https:// doi.org/10.3390/fermentation7020054

Academic Editor: Tiziana Nardi

Received: 12 January 2021

Accepted: 3 April 2021

Published: 6 April 2021

Publisher's Note: MDPI stays neutral with regard to jurisdictional claims in published maps and institutional affiliations.

Copyright: ( $\odot 2021$ by the authors Licensee MDPI, Basel, Switzerland. This article is an open access article distributed under the terms and conditions of the Creative Commons Attribution (CC BY) license (https:// creativecommons.org/licenses/by/ $4.0 /)$.

\begin{abstract}
One of the main targets of sustainable development is the reduction of environmental, social, and economic negative externalities associated with the production of foods and beverages. Those externalities occur at different stages of food chains, from the farm to the fork, with deleterious impacts to different extents. Increasing evidence testifies to the potential of microbial-based solutions and fermentative processes as mitigating strategies to reduce negative externalities in food systems. In several cases, innovative solutions might find in situ applications from the farm to the fork, including advances in food matrices by means of tailored fermentative processes. This viewpoint recalls the attention on microbial biotechnologies as a field of bioeconomy and of 'green' innovations to improve sustainability and resilience of agri-food systems alleviating environmental, economic, and social undesired externalities. We argue that food scientists could systematically consider the potential of microbes as 'mitigating agents' in all research and development activities dealing with fermentation and microbial-based biotechnologies in the agri-food sector. This aims to conciliate process and product innovations with a development respectful of future generations' needs and with the aptitude of the systems to overcome global challenges.
\end{abstract}

Keywords: microbial biotechnologies; biodiversity; fermentation; food; systems; bacteria; yeast; sustainability; resilience; bioeconomy

\section{Microbial Resources and Food Fermentations: The 'Oldest Biotechnologies'}

Microbes, the first forms of life that appeared on Earth at least 3.8 billion years ago, represent the organisms more diffused on the Earth [1,2]. Microorganisms have crucial roles in the environment (cycling of elements and, more generally, of nutrients), in the biology of macroorganisms (of outstanding importance for human, animal, and plant health), and in human advances (e.g., in agriculture, relevant food chains, and biotechnologies) [1,2]. The huge variable in terms of catabolic pathways and for the aptitude to survive to stress conditions make microbes versatile key players on the live planet and drivers of innovations for human activities, such as in biogeochemical processes, biotechnologies, and health [3,4]. Microbes associated with a given 'macroorganism' are defined as their microbiome. Microbiomes are involved in critical physiological activities of their hosts, contributing to the maintenance of a state of well-being. The microbiomes associated with plants and animals domesticated for food uses are fundamental to modulate their productivity and affect the quality of the obtained products.

Since the Neolithic period, humans have developed an unawareness of the management of microbes and experience the benefits of food fermentation, also known as the oldest biotechnologies [5], with a vast variability of raw matrices (cereals, vegetables, and bamboo shoots, legumes, roots/tubers, milk, meat, and fish products) and microorganisms 
involved (bacteria, yeasts, and molds belonging to several genera and species) [6]. It has been estimated that about one-third of the food and beverage consumption worldwide concern fermented matrices: more than 5000 different products that account for an essential part of global systems [6,7]. In general, a given food/beverage is reported as fermented when is "produced through controlled microbial growth, and the conversion of food components through enzymatic action" [8]. The controlled growth of desired bacteria, yeasts, and filamentous fungi modulate all the main aspects of fermented food/beverage safety and quality (organoleptic, nutritional, functional) (Figure 1) [9].

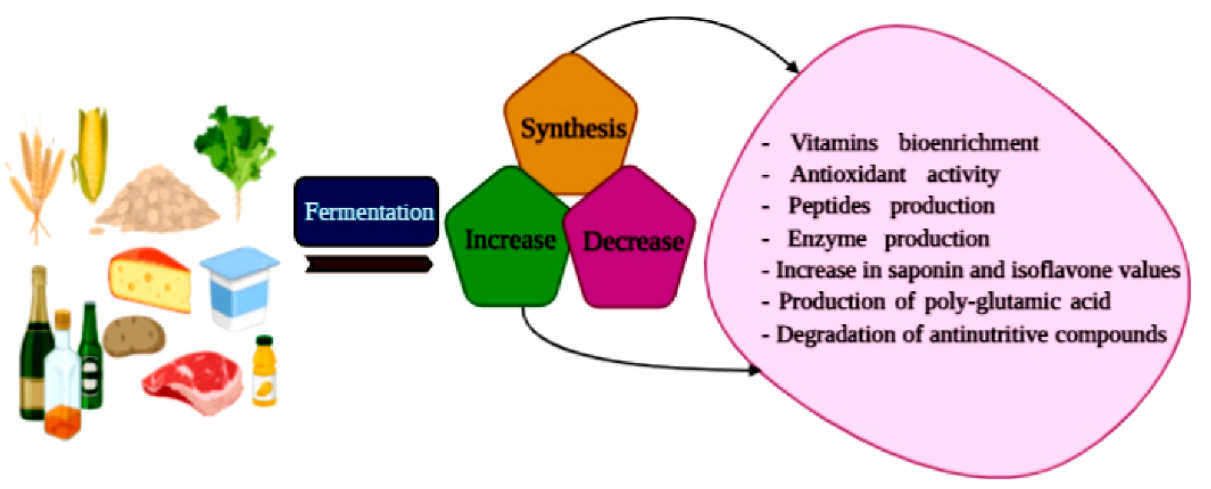

Figure 1. Nutritional enhancement in fermented foods; reproduced from Sharma et al. [10].

In addition, the target of microbial-based solutions has been broadened throughout the advances in microbial biotechnologies. In fact, protective cultures and microbial biocontrol agents can also be found on non-fermented products (e.g., fresh fruits and vegetables, fresh meat) $[11,12]$.

\section{Food Systems and Negative Externalities}

Food systems embrace all resources and activities related to production, processing, distribution, preparation, and food consumption. Also, food systems include the product market, its institutional networks needed for its governance, and it is the ultimate responsibility for the socioeconomic and environmental outcomes of all the activities listed above [13]. According to Organization for Economic Co-operation and Development (OECD), the term externalities 'refers to situations when the effect of production or consumption of goods and services imposes costs or benefits on others which are not reflected in the prices charged for the goods and services being provided' [14].

The idea of sustainable development is tailored to mitigate the negative externalities [15]. In effect, these phenomena undermine the pillars of growth compatible with the needs of future generations. For instance, negative environmental externalities reflect into pollution, natural resource exhaustion/degradation threatening the long-term balance of the ecosystem. These trends also threaten the economic sustainability of markets when companies produce limited quantities leaving unsatisfactory market demand as well as whether companies produce low quality or without placing interest in saving energy, water and preventing pollution. Lastly, negative externalities also challenge sustainable development from a social point of view occur if companies produce with the limited observance of the code of good social responsibility practices: for instance, when companies pay unfair prices to supplies exploiting their work, as well as whether they produce unmatching consumers' and societies' priorities in terms of animal welfare or workers welfare standards.

The rising occurrence of negative externalities generated by food systems has called into action different sectoral stakeholders, such as policymakers, non-governmental organisations (NGOs), and academics, to prioritise the development of strategies contrasting the environmental, economic, and social externalities generated with the food production. Important examples of initiatives are reported in Table 1, testifying the global interest in tailored policies oriented toward sustainability and food systems resilience. 
Table 1. Example of tailored initiatives of policy organisations.

\begin{tabular}{|c|c|c|}
\hline Organisation & Initiatives & Website \\
\hline $\begin{array}{l}\text { United Nations General } \\
\text { Assembly }\end{array}$ & $\begin{array}{l}2030 \text { Agenda, Sustainable } \\
\text { Development Goals (SDGs) }\end{array}$ & $\begin{array}{l}\text { https:/ / www.un.org/ } \\
\text { sustainabledevelopment/, } \\
\text { accessed on } 13 \text { December } 2020\end{array}$ \\
\hline $\begin{array}{l}\text { Food and Agriculture } \\
\text { Organization (FAO) }\end{array}$ & $\begin{array}{l}\text { Food and agriculture in the } \\
2030 \text { Agenda for Sustainable } \\
\text { Development }\end{array}$ & $\begin{array}{l}\text { http://www.fao.org/sustainable- } \\
\text { development-goals/en/, accessed } \\
\text { on } 10 \text { January } 2021\end{array}$ \\
\hline European Commission & Food 2030 & $\begin{array}{l}\text { https://ec.europa.eu/info/ } \\
\text { research-and-innovation/research- } \\
\text { area/food-systems/food-2030_en, } \\
\text { accessed on } 14 \text { December } 2020\end{array}$ \\
\hline $\begin{array}{l}\text { United States } \\
\text { Environmental Protection } \\
\text { Agency }\end{array}$ & $\begin{array}{l}\text { Sustainable Management of } \\
\text { Food }\end{array}$ & $\begin{array}{l}\text { https: / / www.epa.gov/ } \\
\text { sustainable-management-food, } \\
\text { accessed on } 21 \text { December } 2020\end{array}$ \\
\hline $\begin{array}{l}\text { United Kingdom } \\
\text { Government }\end{array}$ & $\begin{array}{l}\text { Food Industry Sustainability } \\
\text { Strategy (FISS) }\end{array}$ & $\begin{array}{l}\text { https:/ / www.gov.uk/government/ } \\
\text { publications/food-industry- } \\
\text { sustainability-strategy-fiss, accessed } \\
\text { on } 20 \text { November } 2020\end{array}$ \\
\hline
\end{tabular}

In association with food production, it is possible to highlight several significant negative externalities, 'namely effects on the environment, the economy and the society that are not reflected in the cost of food' [16]. These include the release of $\mathrm{CO}_{2}$ and other greenhouse gases, increase of wastes and pollution, contamination of freshwater, enhanced water deficiencies, soil depletion, a decrease of biological diversity, reduced benefits of microbiomes, the market of unsafe products, diffused antibiotic resistance, lessening of the supply for selected consumers groups, lastly whether the production is foster the rise of socioeconomic disparities [16-20]. Taken together, these undesirable trends threaten food security (Figure 2), human health, environmental resources, and economic networks, especially if we consider future generations.

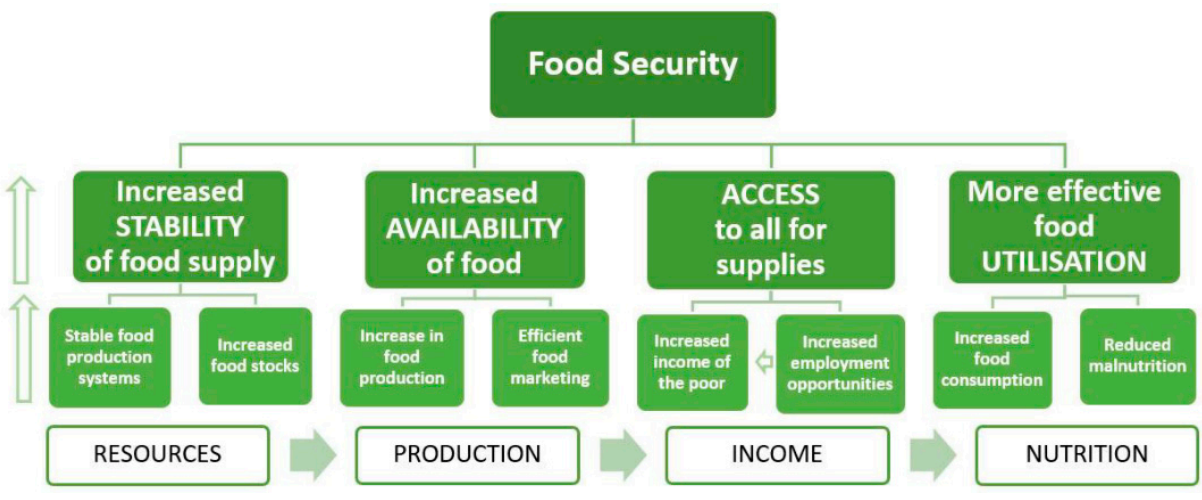

Figure 2. 'Dimensions of food security'; reproduced from Matkovski et al. [21].

\section{Microbial Biotechnologies to Reduce Negative Externalities in Agri-Food Systems}

Microbial-based solutions can find global applications in the food systems, counteracting, at the farm level, to relevant negative externalities on a global scale (Table 2). These include, among others, pollution in the animal/plant food chains, diffusion of contaminations, productions associated with and considerable environmental footprints, and reduction of water availability and soil fertility. 
Table 2. A non-exhaustive list of possible microbial-based solutions as potential mitigating strategies against negative externalities.

\begin{tabular}{ll}
\hline Microbial Biotechnologies to Counteract/Prevent Negative Externalities & Ref. \\
\hline Biological fixation of nitrogen & {$[22-24]$} \\
Alternative nitrogen sources to be used as feed or food & {$[19]$} \\
Microbial protein production & {$[19,25]$} \\
Microbial biotechnology for $\mathrm{CO}_{2}$ capture & {$[19,22]$} \\
Microbial biotechnology to limit diffuse methane emissions & {$[19]$} \\
Microbial-based bioconversion of pollutants in water & {$[19,26,27]$} \\
Microbial-based bioremediation of soil & {$[28,29]$} \\
Microbial biotechnologies for potable water production & {$[30,31]$} \\
Biodegradation of endocrine disruptors from trophic chains & {$[22]$} \\
Optimisation of microbial biofertilizers/biostimulants & {$[32,33]$} \\
Optimisation of microbial biopesticides & {$[32,34]$} \\
Bioprotection and alternatives to antibiotics & {$[35-37]$} \\
Rhizospheric microorganisms for improving the nutrient quality of crops & {$[38,39]$} \\
Beneficial plant-microbe interactions to breed 'microbe-optimized plants' & {$[32]$} \\
Microalgae and new application in food, feed, and nutraceuticals chains & {$[40,41]$} \\
Microbial-based tailored solutions for sustainable feeding regimen & {$[42]$} \\
\hline
\end{tabular}

As reported in the scientific literature, it is possible to find so many examples as to suggest a potential systemic application of microbes as mitigating agents in the primary production. In several cases, the target is the 'remediation' of negative trends: microorganisms selected to reduce carbon dioxide [19,22], bioconversion of pollutants in water via microbial $[19,26,27]$, microbial-driven bioremediation of soil [28,29], and microbial-based decomposition of endocrine disruptors from trophic chains [22]. In addition, we can find 'green' microbial alternatives to standard solutions, such as substitute to antibiotic [35-37], pesticides [32,34], fertilizers/stimulants [32,33], feeding regimen [42], nitrogen sources [19], protein production $[19,25]$, and to make water potable [30,31]. Finally, there are positive activities exerted by microbial resources (e.g., biological fixation of nitrogen [22-24], microalgae beneficial application [40,41], modulation of nutrient crops quality $[38,39]$, and breeding of 'microbe-optimised plants' [32]) that can counteract to the effects of negative externalities.

\section{Tailored Food Fermentative Processes to Reduce Negative Externalities in Food Systems}

Moving from the farm to the fork, we shift from general microbial biotechnologies to food/fermentative biotechnologies (Table 3). This technological exploitation of microorganisms can find direct application in food manufacture, with a considerable potential for in situ uses tailored to modulate specific aspects of food quality and, more generally, food production.

The examples reported in Table 3 encompass a broad spectrum of subjects of interest in the food and beverage industry. A family of solutions reduces the risk of biological and chemical contaminants, respectively, with biocontrol applications against microbial pathogens and spoilers [43-47] and exploiting microbial biochemical activities responsible for the degradation of chemical contaminants [49-51]. Another group of bio-based innovations oriented at 'label cleaning', conceive alternatives to chemical preservatives [52-54] and to fortification via the addition of exogenous nutrients [55-57]. Some studies proposed pathways towards enhanced nutrient bioavailability [10,58-60] and improved human health/well-being [61-64] (including microbiome therapies [63-66]), advances of interest to contrast the adverse effects of some negative externalities. Furthermore, the design of several works looking at reducing resource dissipation, saving energy [52,69], valorising foods by-products [52,70,71], foods wastes [72-74], and wastewater [75-77]. Finally, some strategies can preserve microbial diversity associated with food fermentation [78-80]. 
Table 3. A non-exhaustive list of possible microbial-based solutions as potential mitigating strategies against negative externalities.

\begin{tabular}{ll}
\hline Fermentative Processes to Counteract/Prevent Negative Externalities & Ref. \\
\hline Microbial-based biocontrol of microbial pathogens and spoilers & {$[43-48]$} \\
Microbial-based degradation of chemical contaminants & {$[49-51]$} \\
Bioprotection and alternatives to chemical preservatives & {$[52-54]$} \\
Microbial production of nutrients & {$[55-57]$} \\
Microbes to improve nutrient bioavailability & {$[10,58-60]$} \\
Synbiotic approaches to improve human health and well-being & {$[61-64]$} \\
Microbial biotechnology and microbiome therapies & {$[65-68]$} \\
Microbial resources and strategies to save energy during fermentation & {$[52,69]$} \\
Fermentative valorization of foods by-products & {$[52,70,71]$} \\
Fermentative valorization of foods wastes & {$[72-74]$} \\
Microbial-based valorization of wastewater associated with food systems & {$[75-77]$} \\
Strategies to preserve microbial diversity associated with food fermentation & {$[78-80]$} \\
\hline
\end{tabular}

Some implementations are common to the primary sector and to the studies in food processing. It is the case of protein production that receives interest for both feed and food applications, involving biotechnologies to address a societal or a business need $[19,25]$. Fermentation and microbial cell factories for producing proteins [81], but also enhancing the nutritional quality of alternative protein sources [82].

It is crucial to underline that the safety of the microbial resources, to avoid any negative side-effects, represents a milestone to assure the sustainability of the solutions reported in Tables 2 and 3 [83,84]. At the same time, the management of microbial resources as 'commons', following the standard of microbial biological resource centers (mBRCs), it is of outstanding interest to promote innovation in the field $[85,86]$.

\section{Microbes as Mitigating Agents: A Common Denominator of R\&D Activities in the Field}

This viewpoint article suggests that the challenge of lowering negative externalities would represent a constant part of research and development activities dealing with fermentation and microbial-based biotechnologies in the agri-food sector; a sort of 'lateral thinking' [87] with the aims to conciliate product and process innovations with a development respectful of the needs of future generations. In other terms, as the food industry, together with the 'conventional' quality of the product (e.g., hygienic, sensory, nutritional, functional) [9], has an increasing 'side' focus to sustainable product footprint [88,89], at the same way, food scientists (in the field of microbial-related solutions) could systematically consider the potential as mitigating agents, 'laterally' to the innovation proposed. This in consideration that microbial biotechnologies are a driver of innovation but may play a pivotal role in matching sustainability goals and fostering the agri-food system's resilience. The exploitation of microbial resources is generally considered a knowledgebased reservoir of 'green' innovations susceptible to be used in an environmentally, social, and economically conscious manner [1]. However, microbial biotechnologies' successful implementation needs careful attention since microbial-based solutions are resources of knowledge as created through creative processes and productions and are the primary output of universities and private research centers [90]. Then, microbial biotechnologies are adopted according to the economic conditions in which a company operates as well as to the extent the civil society and consumer accept the use of such biotechnologies [91,92]. Thus, to fully exploit the potential benefits of microbial biotechnologies, there is a need to raise the awareness of their ability to lower the many negative externalities across all the food systems stakeholders (industries, policymakers, academics, and civil society) (Figure 3) $[93,94]$. 


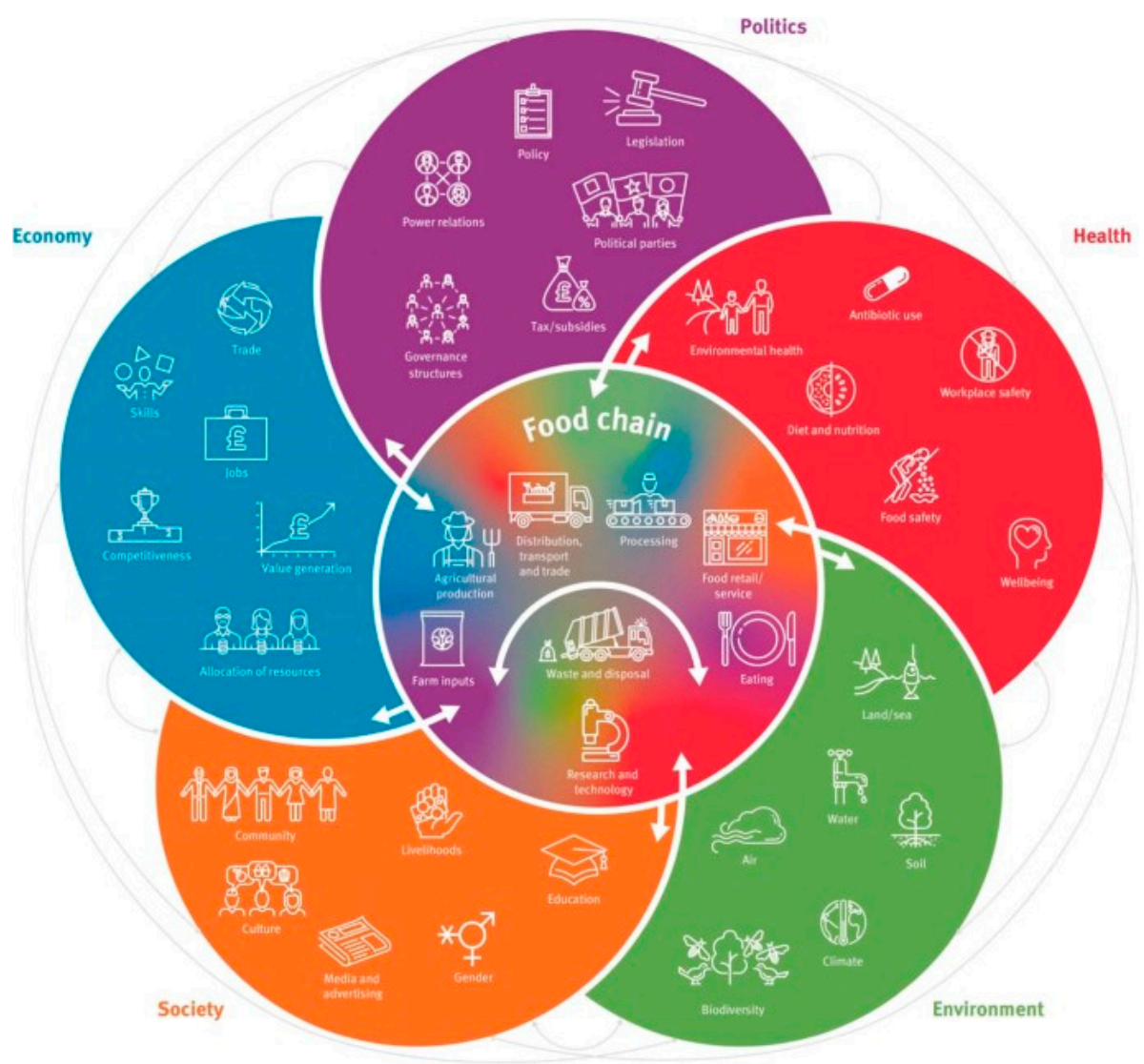

Figure 3. 'Domains within a sustainable food system framework'; reproduced from Tobi et al. [95].

It is important to consider that microbial biotechnology can contribute to economic progress and employment creation [96]. Also, it is worth saying that microbes and fermented base foods are amply accepted by consumers given the widespread use of fermentation across the many food sectors since ancient time, as well as the general consumers' acceptance of microbes and related fermentation is rising due to the consumer demand for a more 'natural' food that replaces chemical preservatives with natural alternatives (biopreservatives) $[91,97]$. These findings contrast the widespread contention that consumers are opposed to the use of biotechnology as they mainly associate biotechnology terms with genetically modified (GM) foods that are, indeed, perceived as an unnatural modification of food and for which consumers ask restrictive policy measures [91,97]. Lastly, related to the microbial biotechnologies and the sustainable economic growth, it is crucial to underline the importance of specific educative programs in the field to favour the people inclination to fair behaviours concerning global challenges such as climate changes and the COVID-19 pandemic [98-101].

Author Contributions: Investigation, V.C., M.F. and F.B.; conceptualization, V.C., M.F. and F.B.; literature Search, V.C., M.F. and F.B.; writing-original draft preparation, V.C., M.F. and F.B.; writingreview and editing, V.C., M.F. and F.B. All authors have read and agreed to the published version of the manuscript.

Funding: This research received no external funding.

Institutional Review Board Statement: Not applicable.

Informed Consent Statement: Not applicable.

Acknowledgments: We would like to thank Domenico Genchi of the Institute of Sciences of Food Production-CNR for its skilled technical support provided during the realisation of this work.

Conflicts of Interest: The authors declare no conflict of interest. 


\section{References}

1. Timmis, K.; de Vos, W.M.; Ramos, J.L.; Vlaeminck, S.E.; Prieto, A.; Danchin, A.; Verstraete, W.; de Lorenzo, V.; Lee, S.Y.; Brüssow, H.; et al. The Contribution of Microbial Biotechnology to Sustainable Development Goals. Microb. Biotechnol. 2017, 10, 984-987. [CrossRef]

2. Cavicchioli, R.; Ripple, W.J.; Timmis, K.N.; Azam, F.; Bakken, L.R.; Baylis, M.; Behrenfeld, M.J.; Boetius, A.; Boyd, P.W.; Classen, A.T.; et al. Scientists' Warning to Humanity: Microorganisms and Climate Change. Nat. Rev. Microbiol. 2019, 17, 569-586. [CrossRef] [PubMed]

3. Martínez-Espinosa, R.M. Microorganisms and Their Metabolic Capabilities in the Context of the Biogeochemical Nitrogen Cycle at Extreme Environments. Int. J. Mol. Sci. 2020, 21, 4228. [CrossRef]

4. Poli, A.; Finore, I.; Romano, I.; Gioiello, A.; Lama, L.; Nicolaus, B. Microbial Diversity in Extreme Marine Habitats and Their Biomolecules. Microorganisms 2017, 5, 25. [CrossRef] [PubMed]

5. Dimidi, E.; Cox, S.R.; Rossi, M.; Whelan, K. Fermented Foods: Definitions and Characteristics, Impact on the Gut Microbiota and Effects on Gastrointestinal Health and Disease. Nutrients 2019, 11, 1806. [CrossRef]

6. Tamang, J.P.; Watanabe, K.; Holzapfel, W.H. Review: Diversity of Microorganisms in Global Fermented Foods and Beverages. Front. Microbiol. 2016, 7. [CrossRef] [PubMed]

7. Vogel, R.F.; Hammes, W.P.; Habermeyer, M.; Engel, K.-H.; Knorr, D.; Eisenbrand, G. Microbial Food Cultures—Opinion of the Senate Commission on Food Safety (SKLM) of the German Research Foundation (DFG). Mol. Nutr. Food Res. 2011, 55, 654-662. [CrossRef]

8. Marco, M.L.; Heeney, D.; Binda, S.; Cifelli, C.J.; Cotter, P.D.; Foligné, B.; Gänzle, M.; Kort, R.; Pasin, G.; Pihlanto, A.; et al. Health Benefits of Fermented Foods: Microbiota and Beyond. Curr. Opin. Biotechnol. 2017, 44, 94-102. [CrossRef] [PubMed]

9. Capozzi, V.; Fragasso, M.; Romaniello, R.; Berbegal, C.; Russo, P.; Spano, G. Spontaneous Food Fermentations and Potential Risks for Human Health. Fermentation 2017, 3, 49. [CrossRef]

10. Sharma, R.; Garg, P.; Kumar, P.; Bhatia, S.K.; Kulshrestha, S. Microbial Fermentation and Its Role in Quality Improvement of Fermented Foods. Fermentation 2020, 6, 106. [CrossRef]

11. De Simone, N.; Pace, B.; Grieco, F.; Chimienti, M.; Tyibilika, V.; Santoro, V.; Capozzi, V.; Colelli, G.; Spano, G.; Russo, P. Botrytis cinerea and Table Grapes: A Review of the Main Physical, Chemical, and Bio-Based Control Treatments in Post-Harvest. Foods 2020, 9, 1138. [CrossRef]

12. Castellano, P.; Pérez Ibarreche, M.; Blanco Massani, M.; Fontana, C.; Vignolo, G.M. Strategies for Pathogen Biocontrol Using Lactic Acid Bacteria and Their Metabolites: A Focus on Meat Ecosystems and Industrial Environments. Microorganisms 2017, 5, 38. [CrossRef]

13. Ruben, R.; Verhagen, J.; Plaisier, C. The Challenge of Food Systems Research: What Difference Does It Make? Sustainability 2019, 11, 171. [CrossRef]

14. OECD Glossary of Statistical Terms_Externalities-OECD Definition. Available online: https://stats.oecd.org/glossary/detail. asp?ID=3215 (accessed on 31 December 2020).

15. Ziolo, M.; Filipiak, B.Z.; Bąk, I.; Cheba, K.; Tîrca, D.M.; Novo-Corti, I. Finance, Sustainability and Negative Externalities. An Overview of the European Context. Sustainability 2019, 11, 4249. [CrossRef]

16. Godfray, H.C.J.; Beddington, J.R.; Crute, I.R.; Haddad, L.; Lawrence, D.; Muir, J.F.; Pretty, J.; Robinson, S.; Thomas, S.M.; Toulmin, C. Food Security: The Challenge of Feeding 9 Billion People. Science 2010, 327, 812-818. [CrossRef]

17. Buzby, J.C.; Hyman, J. Total and per Capita Value of Food Loss in the United States. Food Policy 2012, 37, 561-570. [CrossRef]

18. Shafiee-Jood, M.; Cai, X. Reducing Food Loss and Waste to Enhance Food Security and Environmental Sustainability. Environ. Sci. Technol. 2016, 50, 8432-8443. [CrossRef] [PubMed]

19. Verstraete, W.; Vrieze, J.D. Microbial Technology with Major Potentials for the Urgent Environmental Needs of the next Decades. Microb. Biotechnol. 2017, 10, 988-994. [CrossRef] [PubMed]

20. Russo, P.; Berbegal, C.; De Ceglie, C.; Grieco, F.; Spano, G.; Capozzi, V. Pesticide Residues and Stuck Fermentation in Wine: New Evidences Indicate the Urgent Need of Tailored Regulations. Fermentation 2019, 5, 23. [CrossRef]

21. Matkovski, B.; Đokić, D.; Zekić, S.; Jurjević, Ž. Determining Food Security in Crisis Conditions: A Comparative Analysis of the Western Balkans and the EU. Sustainability 2020, 12, 9924. [CrossRef]

22. de Lorenzo, V. Seven Microbial Bio-Processes to Help the Planet. Microb. Biotechnol. 2017, 10, 995-998. [CrossRef]

23. Soumare, A.; Diedhiou, A.G.; Thuita, M.; Hafidi, M.; Ouhdouch, Y.; Gopalakrishnan, S.; Kouisni, L. Exploiting Biological Nitrogen Fixation: A Route Towards a Sustainable Agriculture. Plants 2020, 9, 1011. [CrossRef]

24. Alaswad, A.A.; Oehrle, N.W.; Krishnan, H.B. Classical Soybean (Glycine Max (L.) Merr) Symbionts, Sinorhizobium fredii USDA191 and Bradyrhizobium diazoefficiens USDA110, Reveal Contrasting Symbiotic Phenotype on Pigeon Pea (Cajanus Cajan (L.) Millsp). Int. J. Mol. Sci. 2019, 20, 1091. [CrossRef]

25. Tagliavia, M.; Nicosia, A. Advanced Strategies for Food-Grade Protein Production: A New E. Coli/Lactic Acid Bacteria Shuttle Vector for Improved Cloning and Food-Grade Expression. Microorganisms 2019, 7, 116. [CrossRef] [PubMed]

26. Ajiboye, T.O.; Kuvarega, A.T.; Onwudiwe, D.C. Recent Strategies for Environmental Remediation of Organochlorine Pesticides. Appl. Sci. 2020, 10, 6286. [CrossRef]

27. Hayat, K.; Menhas, S.; Bundschuh, J.; Chaudhary, H.J. Microbial Biotechnology as an Emerging Industrial Wastewater Treatment Process for Arsenic Mitigation: A Critical Review. J. Clean. Prod. 2017, 151, 427-438. [CrossRef] 
28. Wang, R.; Wu, B.; Zheng, J.; Chen, H.; Rao, P.; Yan, L.; Chai, F. Biodegradation of Total Petroleum Hydrocarbons in Soil: Isolation and Characterization of Bacterial Strains from Oil Contaminated Soil. Appl. Sci. 2020, 10, 4173. [CrossRef]

29. Rigoletto, M.; Calza, P.; Gaggero, E.; Malandrino, M.; Fabbri, D. Bioremediation Methods for the Recovery of Lead-Contaminated Soils: A Review. Appl. Sci. 2020, 10, 3528. [CrossRef]

30. Fowler, S.J.; Smets, B.F. Microbial Biotechnologies for Potable Water Production. Microb. Biotechnol. 2017, 10, 1094-1097. [CrossRef]

31. Byrne, J.M.; Kappler, A. Current and Future Microbiological Strategies to Remove as and Cd from Drinking Water. Microb. Biotechnol. 2017, 10, 1098-1101. [CrossRef]

32. Trivedi, P.; Schenk, P.M.; Wallenstein, M.D.; Singh, B.K. Tiny Microbes, Big Yields: Enhancing Food Crop Production with Biological Solutions. Microb. Biotechnol. 2017, 10, 999-1003. [CrossRef] [PubMed]

33. Backer, R.; Rokem, J.S.; Ilangumaran, G.; Lamont, J.; Praslickova, D.; Ricci, E.; Subramanian, S.; Smith, D.L. Plant GrowthPromoting Rhizobacteria: Context, Mechanisms of Action, and Roadmap to Commercialization of Biostimulants for Sustainable Agriculture. Front. Plant Sci. 2018, 9. [CrossRef] [PubMed]

34. Syed Ab Rahman, S.F.; Singh, E.; Pieterse, C.M.J.; Schenk, P.M. Emerging Microbial Biocontrol Strategies for Plant Pathogens. Plant Sci. 2018, 267, 102-111. [CrossRef] [PubMed]

35. Kawacka, I.; Olejnik-Schmidt, A.; Schmidt, M.; Sip, A. Effectiveness of Phage-Based Inhibition of Listeria monocytogenes in Food Products and Food Processing Environments. Microorganisms 2020, 8, 1764. [CrossRef] [PubMed]

36. Romero-Calle, D.; Guimarães Benevides, R.; Góes-Neto, A.; Billington, C. Bacteriophages as Alternatives to Antibiotics in Clinical Care. Antibiotics 2019, 8, 138. [CrossRef] [PubMed]

37. Nowakiewicz, A.; Zięba, P.; Gnat, S.; Matuszewski, Ł. Last Call for Replacement of Antimicrobials in Animal Production: Modern Challenges, Opportunities, and Potential Solutions. Antibiotics 2020, 9, 883. [CrossRef]

38. Goicoechea, N.; Antolín, M.C. Increased Nutritional Value in Food Crops. Microb. Biotechnol. 2017, 10, 1004-1007. [CrossRef]

39. Pedone-Bonfim, M.V.L.; da Silva, F.S.B.; Maia, L.C. Production of Secondary Metabolites by Mycorrhizal Plants with Medicinal or Nutritional Potential. Acta Physiol. Plant. 2015, 37, 27. [CrossRef]

40. García, J.L.; de Vicente, M.; Galán, B. Microalgae, Old Sustainable Food and Fashion Nutraceuticals. Microb. Biotechnol. 2017, 10, 1017-1024. [CrossRef]

41. Molino, A.; Iovine, A.; Casella, P.; Mehariya, S.; Chianese, S.; Cerbone, A.; Rimauro, J.; Musmarra, D. Microalgae Characterization for Consolidated and New Application in Human Food, Animal Feed and Nutraceuticals. Int. J. Environ. Res. Public Health 2018, 15, 2436. [CrossRef]

42. Immerseel, F.V.; Eeckhaut, V.; Moore, R.J.; Choct, M.; Ducatelle, R. Beneficial Microbial Signals from Alternative Feed Ingredients: A Way to Improve Sustainability of Broiler Production? Microb. Biotechnol. 2017, 10, 1008-1011. [CrossRef] [PubMed]

43. Berbegal, C.; Spano, G.; Fragasso, M.; Grieco, F.; Russo, P.; Capozzi, V. Starter Cultures as Biocontrol Strategy to Prevent Brettanomyces bruxellensis Proliferation in Wine. Appl. Microbiol. Biotechnol. 2018, 102, 569-576. [CrossRef] [PubMed]

44. Berbegal, C.; Garofalo, C.; Russo, P.; Pati, S.; Capozzi, V.; Spano, G. Use of Autochthonous Yeasts and Bacteria in Order to Control Brettanomyces bruxellensis in Wine. Fermentation 2017, 3, 65. [CrossRef]

45. Odedina, G.F.; Vongkamjan, K.; Voravuthikunchai, S.P. Potential Bio-Control Agent from Rhodomyrtus tomentosa against Listeria monocytogenes. Nutrients 2015, 7, 7451-7468. [CrossRef]

46. Russo, P.; Fares, C.; Longo, A.; Spano, G.; Capozzi, V. Lactobacillus plantarum with Broad Antifungal Activity as a Protective Starter Culture for Bread Production. Foods 2017, 6, 110. [CrossRef]

47. Arena, M.P.; Russo, P.; Spano, G.; Capozzi, V. Exploration of the Microbial Biodiversity Associated with North Apulian Sourdoughs and the Effect of the Increasing Number of Inoculated Lactic Acid Bacteria Strains on the Biocontrol against Fungal Spoilage. Fermentation 2019, 5, 97. [CrossRef]

48. De Simone, N.; Capozzi, V.; Amodio, M.L.; Colelli, G.; Spano, G.; Russo, P. Microbial-Based Biocontrol Solutions for Fruits and Vegetables: Recent Insight, Patents, and Innovative Trends. Recent Pat. Food Nutr. Agric. 2021. [CrossRef]

49. Fang, Q.; Du, M.; Chen, J.; Liu, T.; Zheng, Y.; Liao, Z.; Zhong, Q.; Wang, L.; Fang, X.; Wang, J. Degradation and Detoxification of Aflatoxin B1 by Tea-Derived Aspergillus niger RAF106. Toxins 2020, 12, 777. [CrossRef]

50. Ji, C.; Fan, Y.; Zhao, L. Review on Biological Degradation of Mycotoxins. Anim. Nutr. 2016, 2, 127-133. [CrossRef]

51. Russo, P.; Capozzi, V.; Spano, G.; Corbo, M.R.; Sinigaglia, M.; Bevilacqua, A. Metabolites of Microbial Origin with an Impact on Health: Ochratoxin A and Biogenic Amines. Front. Microbiol. 2016, 7, 482. [CrossRef]

52. Nardi, T. Microbial Resources as a Tool for Enhancing Sustainability in Winemaking. Microorganisms 2020, 8, 507. [CrossRef] [PubMed]

53. Mannazzu, I.; Domizio, P.; Carboni, G.; Zara, S.; Zara, G.; Comitini, F.; Budroni, M.; Ciani, M. Yeast Killer Toxins: From Ecological Significance to Application. Crit. Rev. Biotechnol. 2019, 39, 603-617. [CrossRef] [PubMed]

54. Bai, J.; Kim, Y.-T.; Ryu, S.; Lee, J.-H. Biocontrol and Rapid Detection of Food-Borne Pathogens Using Bacteriophages and Endolysins. Front. Microbiol. 2016, 7, 474. [CrossRef] [PubMed]

55. Arena, M.P.; Caggianiello, G.; Russo, P.; Albenzio, M.; Massa, S.; Fiocco, D.; Capozzi, V.; Spano, G. Functional Starters for Functional Yogurt. Foods 2015, 4, 15-33. [CrossRef] [PubMed]

56. Yépez, A.; Russo, P.; Spano, G.; Khomenko, I.; Biasioli, F.; Capozzi, V.; Aznar, R. In Situ Riboflavin Fortification of Different Kefir-like Cereal-Based Beverages Using Selected Andean LAB Strains. Food Microbiol. 2019, 77, 61-68. [CrossRef] 
57. Capozzi, V.; Russo, P.; Fragasso, M.; de Vita, P.; Fiocco, D.; Spano, G. Biotechnology and Pasta-Making: Lactic Acid Bacteria as a New Driver of Innovation. Front. Microbiol. 2012, 3. [CrossRef]

58. Melini, F.; Melini, V.; Luziatelli, F.; Ficca, A.G.; Ruzzi, M. Health-Promoting Components in Fermented Foods: An Up-to-Date Systematic Review. Nutrients 2019, 11, 1189. [CrossRef]

59. Petrova, P.; Petrov, K. Lactic Acid Fermentation of Cereals and Pseudocereals: Ancient Nutritional Biotechnologies with Modern Applications. Nutrients 2020, 12, 1118. [CrossRef]

60. Krausova, G.; Kana, A.; Hyrslova, I.; Mrvikova, I.; Kavkova, M. Development of Selenized Lactic Acid Bacteria and Their Selenium Bioaccummulation Capacity. Fermentation 2020, 6, 91. [CrossRef]

61. Sergeev, I.N.; Aljutaily, T.; Walton, G.; Huarte, E. Effects of Synbiotic Supplement on Human Gut Microbiota, Body Composition and Weight Loss in Obesity. Nutrients 2020, 12, 222. [CrossRef]

62. Arena, M.P.; Russo, P.; Capozzi, V.; Rascón, A.; Felis, G.E.; Spano, G.; Fiocco, D. Combinations of Cereal $\beta$-Glucans and Probiotics Can Enhance the Anti-Inflammatory Activity on Host Cells by a Synergistic Effect. J. Funct. Foods 2016, 23, 12-23. [CrossRef]

63. Markowiak, P.; Śliżewska, K. Effects of Probiotics, Prebiotics, and Synbiotics on Human Health. Nutrients 2017, 9, 1021. [CrossRef] [PubMed]

64. Pérez-Ramos, A.; Mohedano, M.L.; López, P.; Spano, G.; Fiocco, D.; Russo, P.; Capozzi, V. In Situ $\beta$-Glucan Fortification of Cereal-Based Matrices by Pediococcus parvulus 2.6: Technological Aspects and Prebiotic Potential. Int. J. Mol. Sci. 2017, 18, 1588. [CrossRef] [PubMed]

65. O'Toole, P.W.; Paoli, M. The Contribution of Microbial Biotechnology to Sustainable Development Goals: Microbiome Therapies. Microb. Biotechnol. 2017, 10, 1066-1069. [CrossRef] [PubMed]

66. Satokari, R. Modulation of Gut Microbiota for Health by Current and Next-Generation Probiotics. Nutrients $2019,11,1921$. [CrossRef] [PubMed]

67. Shinde, T.; Hansbro, P.M.; Sohal, S.S.; Dingle, P.; Eri, R.; Stanley, R. Microbiota Modulating Nutritional Approaches to Countering the Effects of Viral Respiratory Infections Including SARS-CoV-2 through Promoting Metabolic and Immune Fitness with Probiotics and Plant Bioactives. Microorganisms 2020, 8, 921. [CrossRef]

68. Barathikannan, K.; Chelliah, R.; Rubab, M.; Daliri, E.B.-M.; Elahi, F.; Kim, D.-H.; Agastian, P.; Oh, S.-Y.; Oh, D.H. Gut Microbiome Modulation Based on Probiotic Application for Anti-Obesity: A Review on Efficacy and Validation. Microorganisms 2019, 7, 456. [CrossRef]

69. Berbegal, C.; Fragasso, M.; Russo, P.; Bimbo, F.; Grieco, F.; Spano, G.; Capozzi, V. Climate Changes and Food Quality: The Potential of Microbial Activities as Mitigating Strategies in the Wine Sector. Fermentation 2019, 5, 85. [CrossRef]

70. Karlović, A.; Jurić, A.; Ćorić, N.; Habschied, K.; Krstanović, V.; Mastanjević, K. By-Products in the Malting and Brewing Industries-Re-Usage Possibilities. Fermentation 2020, 6, 82. [CrossRef]

71. Mora-Villalobos, J.A.; Montero-Zamora, J.; Barboza, N.; Rojas-Garbanzo, C.; Usaga, J.; Redondo-Solano, M.; Schroedter, L.; Olszewska-Widdrat, A.; López-Gómez, J.P. Multi-Product Lactic Acid Bacteria Fermentations: A Review. Fermentation 2020 , 6, 23. [CrossRef]

72. Costa, S.; Summa, D.; Semeraro, B.; Zappaterra, F.; Rugiero, I.; Tamburini, E. Fermentation as a Strategy for Bio-Transforming Waste into Resources: Lactic Acid Production from Agri-Food Residues. Fermentation 2021, 7, 3. [CrossRef]

73. Krull, S.; Brock, S.; Prüße, U.; Kuenz, A. Hydrolyzed Agricultural Residues-Low-Cost Nutrient Sources for 1-Lactic Acid Production. Fermentation 2020, 6, 97. [CrossRef]

74. Alexandri, M.; López-Gómez, J.P.; Olszewska-Widdrat, A.; Venus, J. Valorising Agro-Industrial Wastes within the Circular Bioeconomy Concept: The Case of Defatted Rice Bran with Emphasis on Bioconversion Strategies. Fermentation $2020,6,42$. [CrossRef]

75. Kurniawan, A.; Kwon, S.Y.; Shin, J.-H.; Hur, J.; Cho, J. Acid Fermentation Process Combined with Post Denitrification for the Treatment of Primary Sludge and Wastewater with High Strength Nitrate. Water 2016, 8, 117. [CrossRef]

76. Souza Filho, P.F.; Brancoli, P.; Bolton, K.; Zamani, A.; Taherzadeh, M.J. Techno-Economic and Life Cycle Assessment of Wastewater Management from Potato Starch Production: Present Status and Alternative Biotreatments. Fermentation 2017, 3, 56. [CrossRef]

77. Harb, M.; Hong, P.-Y. Anaerobic Membrane Bioreactor Effluent Reuse: A Review of Microbial Safety Concerns. Fermentation 2017, 3, 39. [CrossRef]

78. Capozzi, V.; Fragasso, M.; Russo, P. Microbiological Safety and the Management of Microbial Resources in Artisanal Foods and Beverages: The Need for a Transdisciplinary Assessment to Conciliate Actual Trends and Risks Avoidance. Microorganisms 2020, 8, 306. [CrossRef] [PubMed]

79. Capozzi, V.; Russo, P.; Spano, G. Microbial Information Regimen in EU Geographical Indications. World Pat. Inf. 2012, 34, $229-231$. [CrossRef]

80. Spano, G.; Capozzi, V. Food Microbial Biodiversity and "Microbes of Protected Origin". Front. Microbiol. 2011, 2. [CrossRef]

81. Matassa, S.; Boon, N.; Pikaar, I.; Verstraete, W. Microbial Protein: Future Sustainable Food Supply Route with Low Environmental Footprint. Microb. Biotechnol. 2016, 9, 568-575. [CrossRef]

82. Kårlund, A.; Gómez-Gallego, C.; Korhonen, J.; Palo-oja, O.-M.; El-Nezami, H.; Kolehmainen, M. Harnessing Microbes for Sustainable Development: Food Fermentation as a Tool for Improving the Nutritional Quality of Alternative Protein Sources. Nutrients 2020, 12, 1020. [CrossRef] 
83. Berbegal, C.; Borruso, L.; Fragasso, M.; Tufariello, M.; Russo, P.; Brusetti, L.; Spano, G.; Capozzi, V. A Metagenomic-Based Approach for the Characterization of Bacterial Diversity Associated with Spontaneous Malolactic Fermentations in Wine. Int. J. Mol. Sci. 2019, 20, 3980. [CrossRef] [PubMed]

84. Russo, P.; Spano, G.; Capozzi, V. Safety evaluation of starter cultures. In Starter Cultures in Food Production; John Wiley \& Sons, Ltd.: Hoboken, NJ, USA, 2017; pp. 101-128, ISBN 978-1-118-93379-4.

85. Stackebrandt, E.; Schüngel, M.; Martin, D.; Smith, D. The Microbial Resource Research Infrastructure MIRRI: Strength through Coordination. Microorganisms 2015, 3, 890-902. [CrossRef] [PubMed]

86. De Vero, L.; Boniotti, M.B.; Budroni, M.; Buzzini, P.; Cassanelli, S.; Comunian, R.; Gullo, M.; Logrieco, A.F.; Mannazzu, I.; Musumeci, R.; et al. Preservation, Characterization and Exploitation of Microbial Biodiversity: The Perspective of the Italian Network of Culture Collections. Microorganisms 2019, 7, 685. [CrossRef]

87. de Bono, E. Lateral Thinking; Creativity Step by Step; Penguin: London, UK, 1970.

88. Topleva, S.A.; Prokopov, T.V. Integrated Business Model for Sustainability of Small and Medium-Sized Enterprises in the Food Industry: Creating Value Added through Ecodesign. Br. Food J. 2020, 122, 1463-1483. [CrossRef]

89. Toussaint, M.; Cabanelas, P.; González-Alvarado, T.E. What about the Consumer Choice? The Influence of Social Sustainability on Consumer's Purchasing Behavior in the Food Value Chain. Eur. Res. Manag. Bus. Econ. 2021, 27, 100134. [CrossRef]

90. Demain, A.L. Microbial Biotechnology. Trends Biotechnol. 2000, 18, 26-31. [CrossRef]

91. Pakseresht, A.; McFadden, B.R.; Lagerkvist, C.J. Consumer Acceptance of Food Biotechnology Based on Policy Context and Upstream Acceptance: Evidence from an Artefactual Field Experiment. Eur. Rev. Agric. Econ. 2017, 44, 757-780. [CrossRef]

92. McFadden, J.R.; Huffman, W.E. Consumer Valuation of Information about Food Safety Achieved Using Biotechnology: Evidence from New Potato Products. Food Policy 2017, 69, 82-96. [CrossRef]

93. Roman, M.; Varga, H.; Cvijanovic, V.; Reid, A. Quadruple Helix Models for Sustainable Regional Innovation: Engaging and Facilitating Civil Society Participation. Economies 2020, 8, 48. [CrossRef]

94. Leydesdorff, L. The Triple Helix, Quadruple Helix, ..., and an N-Tuple of Helices: Explanatory Models for Analyzing the Knowledge-Based Economy? J. Knowl. Econ. 2012, 3, 25-35. [CrossRef]

95. Tobi, R.C.A.; Harris, F.; Rana, R.; Brown, K.A.; Quaife, M.; Green, R. Sustainable Diet Dimensions. Comparing Consumer Preference for Nutrition, Environmental and Social Responsibility Food Labelling: A Systematic Review. Sustainability 2019, 11, 6575. [CrossRef]

96. Timmis, K.; de Lorenzo, V.; Verstraete, W.; Ramos, J.L.; Danchin, A.; Brüssow, H.; Singh, B.K.; Timmis, J.K. The Contribution of Microbial Biotechnology to Economic Growth and Employment Creation. Microb. Biotechnol. 2017, 10, 1137-1144. [CrossRef] [PubMed]

97. Doyle, M.P.; Steenson, L.R.; Meng, J. Bacteria in Food and Beverage Production. In The Prokaryotes: Applied Bacteriology and Biotechnology; Rosenberg, E., DeLong, E.F., Lory, S., Stackebrandt, E., Thompson, F., Eds.; Springer: Berlin/Heidelberg, Germany, 2013; pp. 241-256, ISBN 978-3-642-31331-8.

98. Timmis, K.; Cavicchioli, R.; Garcia, J.L.; Nogales, B.; Chavarría, M.; Stein, L.; McGenity, T.J.; Webster, N.; Singh, B.K.; Handelsman, J.; et al. The Urgent Need for Microbiology Literacy in Society. Environ. Microbiol. 2019, 21, 1513-1528. [CrossRef] [PubMed]

99. Galanakis, C.M. The Food Systems in the Era of the Coronavirus (COVID-19) Pandemic Crisis. Foods 2020, 9, 523. [CrossRef]

100. Eilam, E.; Prasad, V.; Widdop Quinton, H. Climate Change Education: Mapping the Nature of Climate Change, the Content Knowledge and Examination of Enactment in Upper Secondary Victorian Curriculum. Sustainability 2020, 12, 591. [CrossRef]

101. Capozzi, V.; Spano, G.; Fiocco, D. Transdisciplinarity and Microbiology Education. J. Microbiol. Biol. Educ. JMBE 2012, 13, 70-73. [CrossRef] [PubMed] 